\title{
Absorption Wavelength Extension for Dye-Sensitized Solar Cells by Varying the Substituents of Chiral Salen Cu(II) Complexes
}

\author{
Ryosuke Shoji ${ }^{1}$, Shun Ikenomoto $^{1}$, Nobumitsu Sunaga ${ }^{1}$, Mutsumi Sugiyama ${ }^{2}$ and \\ Takashiro Akitsu,
}

${ }^{1}$ Department of Chemistry, Faculty of Science, Tokyo University of Science, 1-3 Kagurazaka, Shinjuku-ku, Tokyo 162-8601, Japan

${ }^{2}$ Department of Electrical Engineering, Faculty of Science and Technology, Tokyo University of Science, 2641 Yamazaki, Noda, Chiba 278-8510, Japan

\begin{abstract}
New chiral salen-type Cu(II) complexes (1-9) were prepared, and the effects of different substituent groups on their absorption spectra were evaluated using time-dependent density functional theory (TD-DFT). Electron withdrawing groups resulted in a red-shift and an increase in the peak intensity. According to cyclic voltammetry analyses, the introduction of electron withdrawing groups brought the redox potentials $\left(E^{0}\right)$ in agreement with the orbital level energies determined via TD-DFT. The reduction potentials for 1-9 are less than $-0.500 \mathrm{~V}$, and therefore, it is electrochemically possible to dope electrons in $\mathrm{TiO}_{2}$. In addition, the oxidation potentials are greater than $+0.200 \mathrm{~V}$, indicating that it is electrochemically possible to regenerate the dyes. Preproduction dye-sensitized solar cells (DSSCs) fabricated using compounds 1-9 generated electricity. In particular, the DSSC prepared using 2 (which has electron withdrawing groups and the largest maximum absorption) exceeded the power conversion efficiency of DSSC fabricated using N3, which is a commonly used $\mathrm{Ru}(\mathrm{II})$ complex.
\end{abstract}

Keywords: DSSC, Copper(II), Schiff base, Chirality, Crystal structure.

\section{INTRODUCTION}

Various mechanisms to provide improved current generation efficiencies in dye-sensitised solar cells (DSSCs) have been devised [1-7]. Recently, the power conversion efficiencies (PCEs) of DSSCs have improved due to the use of new photosensitisers such as $\mathrm{Ru}$ (II) complexes. To further improve the PCE of DSSCs, however, it is necessary to find dyes that absorb photons efficiently over the entire visible and near-infrared (NIR) regions. The compound N719 ([RuL $\left.{ }_{2}(\mathrm{NCS})_{2}\right]$ :2TBA; L=2,2'-bipyridyl-4,4'-dicarboxylic acid, TBA = tetra- $n$-butyl ammonium) is known to achieve photoelectric conversion to $900 \mathrm{~nm}$ [8]. However, $\mathbf{N 7 1 9}$ is susceptible to degrade through the dissociation of its labile NCS ligands. Therefore, to improve the dye stability, the replacement of the $\mathrm{NCS}^{-}$ ligands with chelating ligands such as naphthalimide, porphyrin $\mathrm{Zn}$ (II) complexes or phthalocyanine $\mathrm{Cu}(\mathrm{II})$ complexes, has been investigated $[9,10]$.

Dyes have also been shown to adsorb on $\mathrm{TiO}_{2}$ surface via interaction with the Ti2p and O1s orbitals of their carboxy groups [11]. However, dyes such as N719 and N3 $\left(\mathrm{RuL}_{2}(\mathrm{NCS})_{2} ; \mathrm{L}=2,2\right.$ '-bipyridyl-4,4'-dicarboxylic acid), which contain $\mathrm{NCS}^{-}$ligands, adsorb on $\mathrm{TiO}_{2}$ via the interactions of their $\mathrm{S}$ atoms. Therefore, the control

*Address correspondence to this author at the Department of Chemistry, Faculty of Science, Tokyo University of Science, 1-3 Kagurazaka, Shinjuku-ku, Tokyo 162-8601, Japan; Tel: +81-3-5228-8271;

E-mail: akitsu@rs.kagu.tus.ac.jp of the adsorption structure via co-adsorption has been reported [12].

Our focus has been on salen metal complexes because they have the following characteristics:

(1) Their synthesis and chemical modification are easier than what is required for existing dyes.

(2) They have higher stability than existing dyes due to the presence of chelating ligands.

(3) They have various interesting magnetic and optical properties and oxidation-reduction reactivities due to their electron transfer behaviour.

(4) They are known to catalyse asymmetric synthesis and redox reactions $[13,14]$.

Therefore, salen metal complexes have potential for use as dyes in DSSCs. Increasing the PCE of salen $\mathrm{Zn}$ (II) complexes by varying the substituents has been reported [15]. In addition, the UV-vis spectra of salen $\mathrm{Al}(\mathrm{III})$ complexes were found to be red-shifted following the incorporation of electron-withdrawing substituents [16]. It is therefore expected that substituent effects in salen metal complexes should be useful for controlling absorption across the visible and NIR regions as well as $\mathrm{E}^{0}$ values.

It is also known that the interactions between chiral molecules and nanoparticles or semiconductors 
produce new circular dichroism (CD) signals due to dipole interactions and dielectric effects $[17,18]$. Thus, the interaction of chiral salen metal complexes with $\mathrm{TiO}_{2}$ should result in the expansion of the wavelength region over which these complexes absorb light, which is conventional but effective strategy.

To design DSSC dyes, we therefore investigated the effect of the different substituents in $\mathrm{Cu}(\mathrm{II})$ salen complexes 1-9, involving common metal $\mathrm{Cu}(\mathrm{II})$, on the shift of their absorbances to the NIR region and their reduction potentials (Figure 1 ). The performance of DSSC devices based on the complexes was also achieved and compared to that of a DSSC based on N3.

\section{RESULTS AND DISCUSSION}

As shown in Figure $\mathbf{1}, \mathbf{1}$ is a five-coordinated mononuclear $\mathrm{Cu}$ (II) complex with a square pyramidal

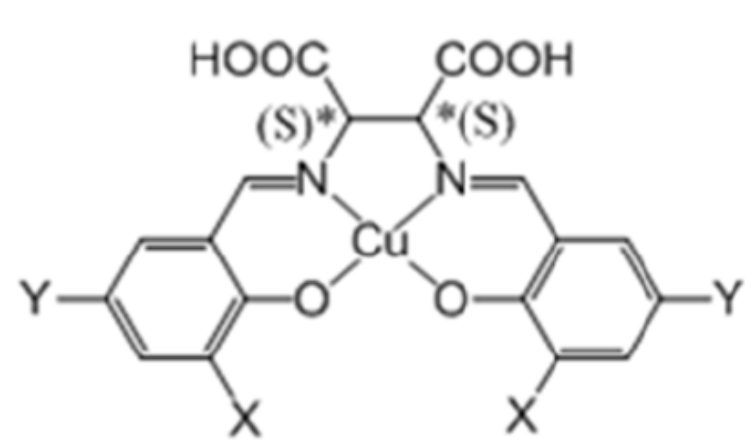

$\mathbf{X}$

$1 \mathrm{H}-$

2 Cl-

$3 \mathrm{Br}-$

4 t-Bu-

$5 \mathrm{MeO}-$

$6 \mathrm{HO}-$

$7 \mathrm{H}-$

$8 \mathrm{H}-$

$9 \mathrm{H}-$
$\mathbf{Y}$

$\mathrm{H}-$

Cl-

$\mathrm{Br}-$

t-Bu-

H-

H-

Cl-

Br-

$\mathrm{MeO}-$
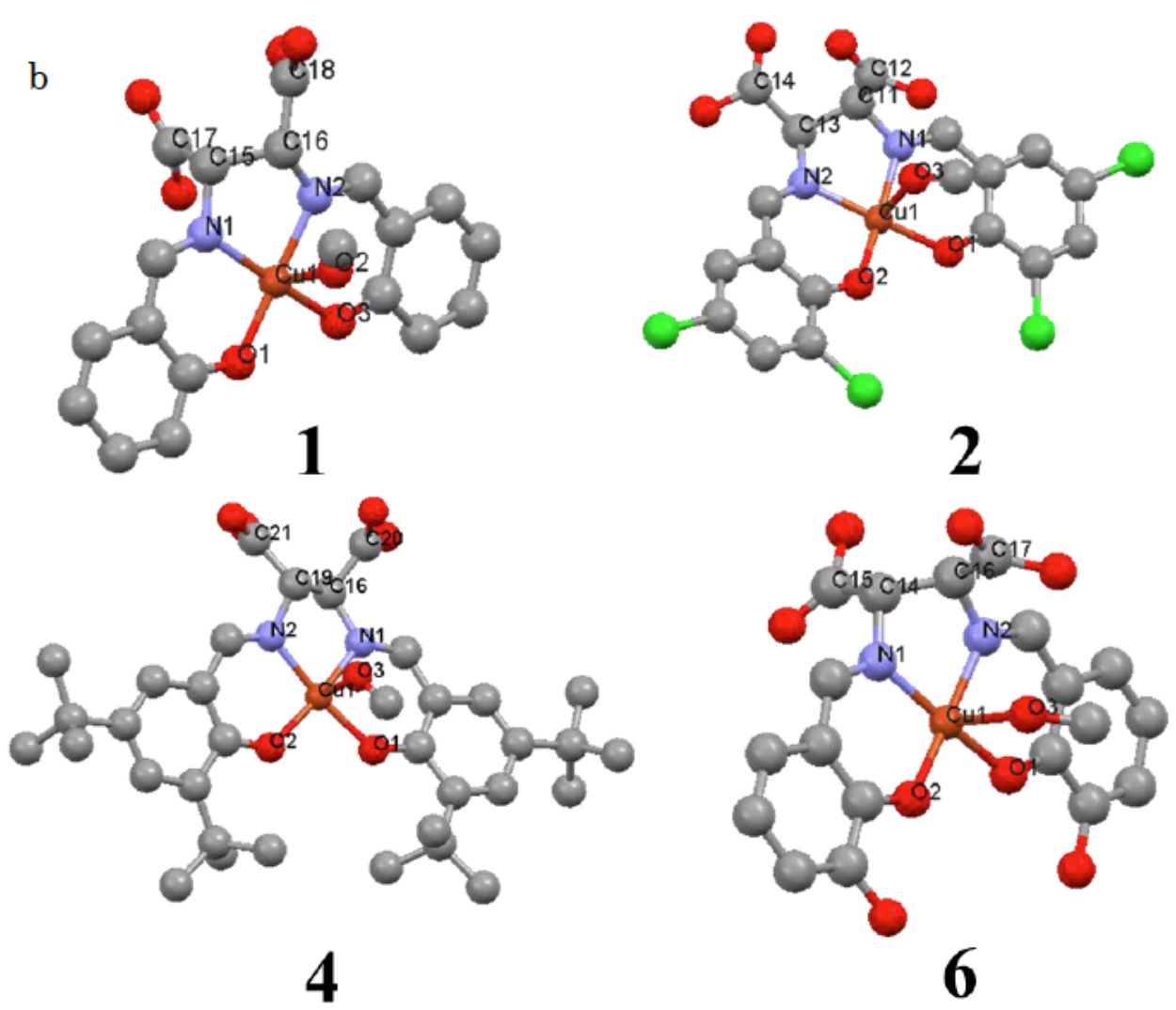

Figure 1: (a) Chiral salen $\mathrm{Cu}(\mathrm{II})$ complexes 1-9 and (b) molecular structures of 1, 2, 4 and 6. Hydrogen atoms are omitted for clarity. 
$\left[\mathrm{CuN}_{2} \mathrm{O}_{3}\right]$ geometry. The four donor atoms of the tetradentate Schiff base form the equatorial plane, and $\mathrm{MeOH}$ ligands occupy the axial sites with the Cu1-O1, Cu1-O3, Cu1-N1 and Cu1-N2 bond distances ranging from 1.9141(5) to 2.0711(5) $\AA$ and the Cu1-O2 bond distance for the axial O atom of 2.0491(5) $\AA$ (Table 1). The chiral (2S,3S)-3-aminoaspartic acid moiety adopts a $\lambda$ configuration. Structures of 2,4 and 6 are summarised in Tables S1-S4.

The torsion angles of complexes 1, 2, 4 and 6 may be affected by the electron donating groups of the two substituents (X-). In particular, the contortion of the torsion angle is thought to be due to the repulsion of the electrons of the carboxy groups qualitatively. Thus, because the complexes should interact with $\mathrm{TiO}_{2}$ through the carboxy groups, the changes in the torsion angles due to the substituents should affect the distance between each adsorbed complex and $\mathrm{TiO}_{2}$, which in turn should influence their current densityvoltage $(J-V)$ properties.

Figures $2 \mathbf{a}$ and $\mathbf{b}$ depict the UV-vis-NIR and CD spectra (solid state and DMF solutions, respectively) for complexes 1-9. A comparison of the UV-vis-NIR spectra of the complexes revealed the role of the substituents in the salen ligand. It can be clearly seen that the $\pi-\Pi^{*}$ absorbance bands in the diffuse reflectance electronic spectra were red-shifted in the order $\mathbf{7}>\mathbf{9}>\mathbf{3}>\mathbf{5}>\mathbf{2}>\mathbf{4}>\mathbf{8}>\mathbf{6}>\mathbf{1}$. These results indicate that the $\mathrm{Cu}(\mathrm{II})$ complexes containing two substituents $(\mathrm{Y}-)$ and electron withdrawing groups had more significantly red-shifted peaks. The large difference in the red-shifts for the peaks for complexes 8 and 7, which have $\mathrm{Br}$ - and $\mathrm{Cl}$ - substituents, respectively, can be attributed to the difference in the electronegativities of $\mathrm{Cl}$ and $\mathrm{Br}$. Therefore, the red-shift of the $\pi-\pi^{*}$ band increased when the complexes contained two substituents ( $Y$-) and/or the substituent was an electron withdrawing group with a high electronegativity. In addition, the $d-d$ bands in the diffuse reflectance electronic spectra of the complexes were red-shifted in the order $2>4>9>7>3>5>1>$ $8>6$. The results also indicate that the incorporation of ligands in the $\mathrm{Cu}$ (II) complexes with electron withdrawing groups contributed significantly to the redshift. For example, the $d-d$ band for complex $\mathbf{5}(X-)$ was

Table 1a: Crystallographic Data for 1

\begin{tabular}{|c|c|}
\hline Empirical formula & $\mathrm{C}_{19} \mathrm{H}_{18} \mathrm{CuN}_{2} \mathrm{O}_{7}$ \\
\hline Formula weight & 449.90 \\
\hline Crystal system & Monoclinic \\
\hline Space group & $P 2_{1} / \mathrm{n}(\# 14)$ \\
\hline$a(\AA)$ & $14.3880(5)$ \\
\hline$b(\AA)$ & $18.7418(18)$ \\
\hline$c(\AA)$ & $13.2804(16)$ \\
\hline$\beta\left({ }^{\circ}\right)$ & $91.358(9)$ \\
\hline$V\left(\AA^{3}\right)$ & $3580(2)$ \\
\hline$Z$ & 4 \\
\hline$R w p(\%)$ & 15.53 \\
\hline
\end{tabular}

Table 1b: Selected Bond Lengths and Angles for 1

\begin{tabular}{|c|c|c|c|}
\hline Cu 1 - O 1 & $1.9141(5) \AA$ & O 1 - Cu 1 - O 3 & $92.07(3)^{\circ}$ \\
\hline Cu 1 - O 2 & $2.0491(5) \AA$ & $\mathrm{O} 1-\mathrm{Cu} 1-\mathrm{N} 1$ & $91.44(3)^{\circ}$ \\
\hline Cu 1 - O 3 & $1.9869(5) \AA$ & O 1 - Cu 1 - N 2 & $170.6731(15)^{\circ}$ \\
\hline Cu 1 - N 1 & $2.0711(5) \AA ̊$ & O 2 - Cu 1 - N 1 & $89.25(2)^{\circ}$ \\
\hline Cu 1 - N 2 & $2.0002(5) \AA ̊$ & O $3-\mathrm{Cu} 1-\mathrm{N} 1$ & $172.365(2)^{\circ}$ \\
\hline & & O 3 - Cu 1 - N 2 & $93.52(3)^{\circ}$ \\
\hline & & N $1-\mathrm{Cu} 1-\mathrm{N} 2$ & $83.91(3)^{\circ}$ \\
\hline
\end{tabular}


a
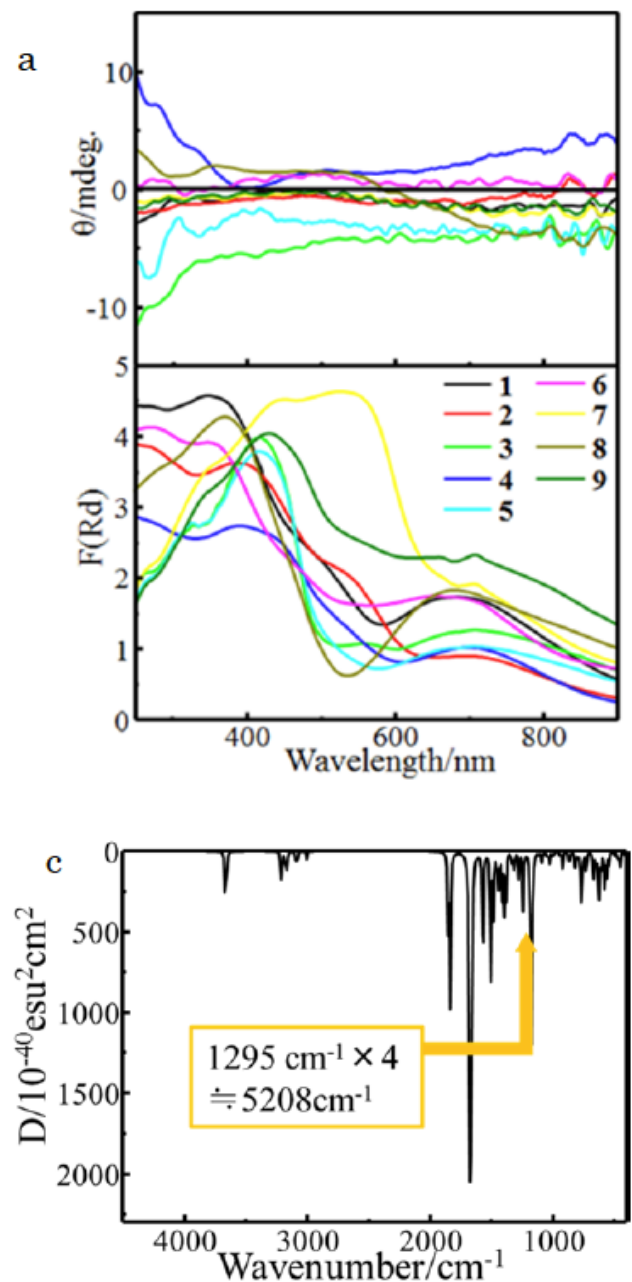

$\mathrm{b}$
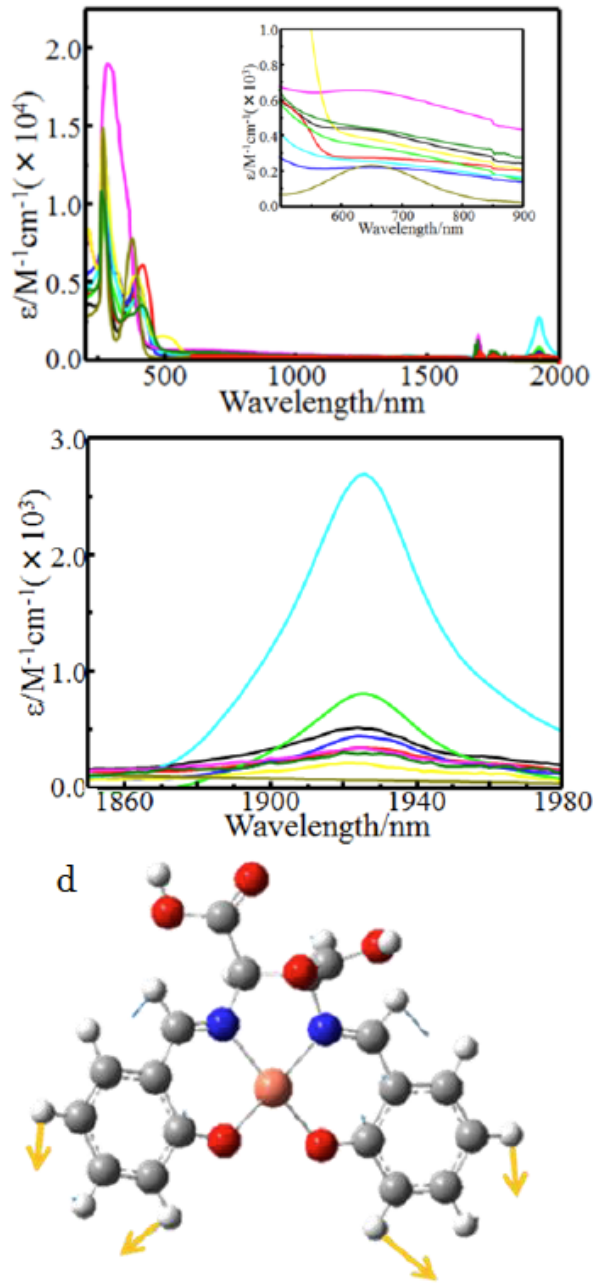

Figure 2: UV-vis-NIR and CD spectra of complexes 1-9 in the (a) solid state and (b) DMF solution, (c) calculated IR spectra of $\mathbf{1}$ and (d) normal vibrations of $\mathbf{1}$.

red-shifted much more significantly than that for complex $\mathbf{9}(\mathrm{Y}-)$. Therefore, it can be concluded that the incorporation of an electron withdrawing substituent at position X- has a large effect on the red-shift of the $d-d$ band in these $\mathrm{Cu}(\mathrm{II})$ salen complexes. The correlation mainly mentions not slight difference of electronegativity of substituent groups but the number of electron-withdrawing groups. We thought that NIR band contribute vibronic coupling to absorb UV light which directly occurs photo-induced electron transfer. In general dye complexes of DSSC adsorb chemically onto (Lewis acidic) $\mathrm{TiO}_{2}$ as deprotonated form. We assumed protonated form of the complexes as this model.

The absorption intensities of the $\pi-\pi^{*}$ transitions for all the complexes 1-9 were in the range of $10^{4}$, and as the absorption wavelength shifted due to the incorporation of electron withdrawing groups, the intensity increased. Conversely, the absorption intensities of the $d-d$ transitions were of the order of
$10^{2}$, and the influence of the electron withdrawing substituents was less than that observed for the $\pi-\Pi^{*}$ transitions. Note that the absorption at approximately $1900 \mathrm{~nm}$ had an intensity of the order of $10^{3}$ for all the complexes. Complex 5, in particular, exhibited a striking change in intensity for this peak, as can be seen in Figure 2b. These absorptions near 1900 nm are attributed to the vibrations of overtone effects (Figures 2c and d).

To rationalise the importance of the molecular electronic structures associated with the $X$ - and $Y$ groups in 1-9, simulated UV-vis and CD spectra and the molecular orbitals of the ground and excited states were calculated for each, and the results for $\mathbf{1}$ are shown in Figures 3a-c, respectively.

The electron transfer data for all the chiral salen $\mathrm{Cu}$ (II) complexes 1-9 when adsorbed on $\mathrm{TiO}_{2}$ are provided in Table S5. In complexes $\mathbf{1}$ and $\mathbf{6}$, the predominant absorption bands were assigned as 

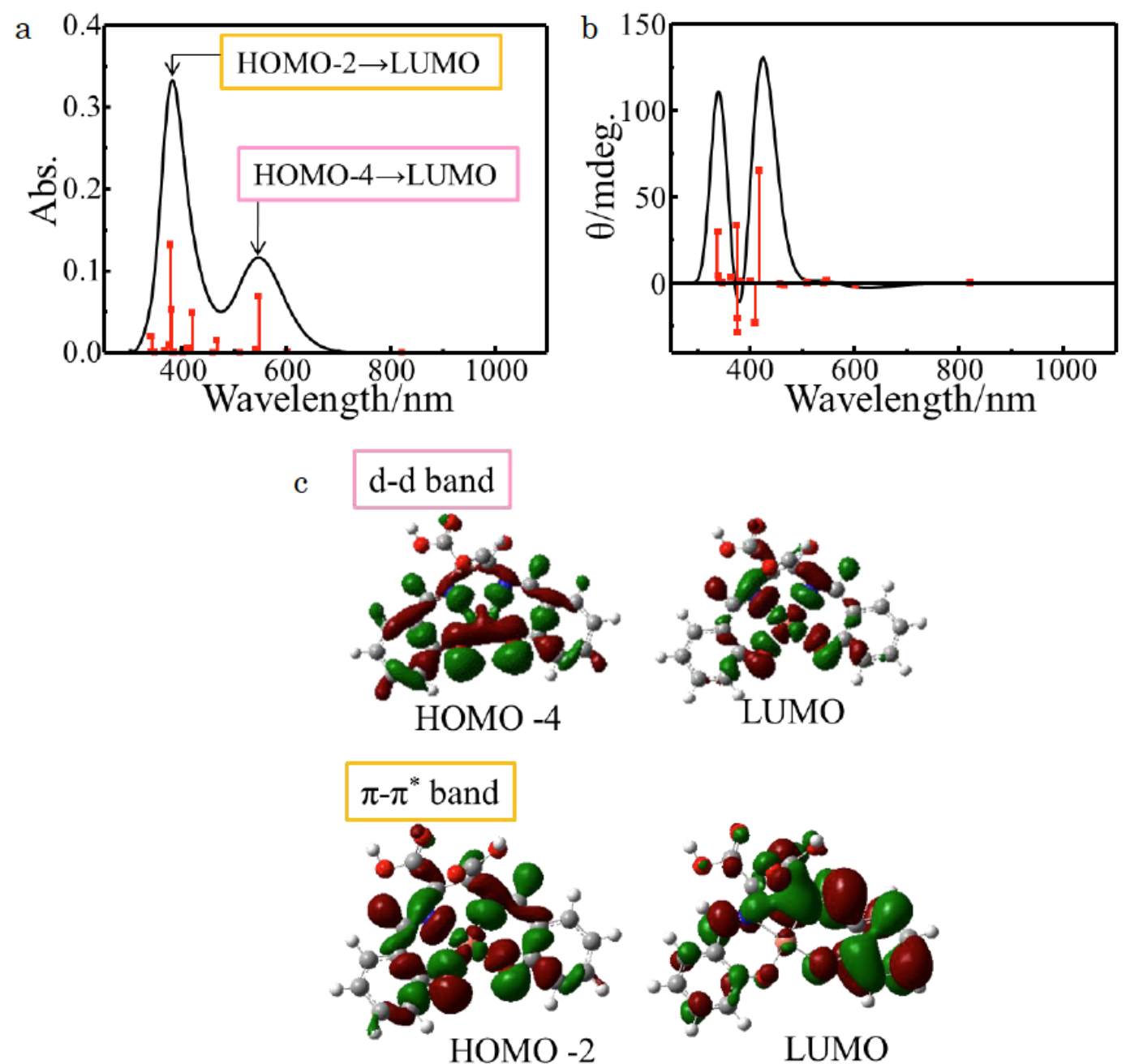

Figure 3: (a) Simulated UV-vis spectra, (b) simulated CD spectra and (c) molecular orbitals for the ground state (HOMO) and excited state (LUMO) of 1.

transitions from the highest occupied molecular orbital (HOMO-4) to the lowest unoccupied molecular orbital (LUMO), which is distributed on the amine moieties. Based on these results, it is reasonable to conclude that the spectral shifts were due to the substitution of the $\mathrm{X}$ - and $\mathrm{Y}$ - groups. The electron transfer in all the complexes 1-9 occurred first to the aldehyde, then to the central metal and finally to the diamine. In addition, after electron transfer, the electron density was distributed on the carboxy groups. Therefore, it can be concluded that the electrons were transferred from the $\mathrm{Cu}$ (II) salen complexes to $\mathrm{TiO}_{2}$.

The electrochemical properties of the complexes 19 were determined using cyclic voltammetry (CV) and are presented in Table S6. It can be seen in Figure 4a that the energy level for the conduction band (CB) of $\mathrm{TiO}_{2}$ was located between that of the LUMOs and HOMOs of the salen Cu dyes. The LUMOs of all the complexes were lower than the $\mathrm{CB}$ minimum of $\mathrm{TiO}_{2}$
$(-0.500 \mathrm{~V})$, while the HOMOs of all the complexes were higher than the $\mathrm{I}_{3}{ }^{-} / \mathrm{I}^{-}$potential of $\mathrm{TiO}_{2}(-0.200 \mathrm{~V})$. Therefore, all the complexes 1-9 should be able to dope electrons in $\mathrm{TiO}_{2}$ and undergo regeneration. In addition, the electrochemical behaviour of all the complexes 1-9 was reversible; the current values remained unchanged after repeated CV cycles, indicating that no changes in the structures of the complexes occurred. Therefore, it can be concluded that the central $\mathrm{Cu}$ metal participated in the redox reactions.

Table S7 summarises the absorption wavelengths, energy levels, redox potentials and calculated HOMOLUMO gaps for the HOMOs and LUMOs of compounds 1-9. In addition, the correlation between the $\pi-\pi{ }^{*}$ band and the HOMO-LUMO gap is shown in Figure $\mathbf{4 b}$. The relationships between the wavenumbers of the $\pi-\pi^{*}$ band and the HOMO-LUMO gap correlated well for both the measured and calculated values obtained via 

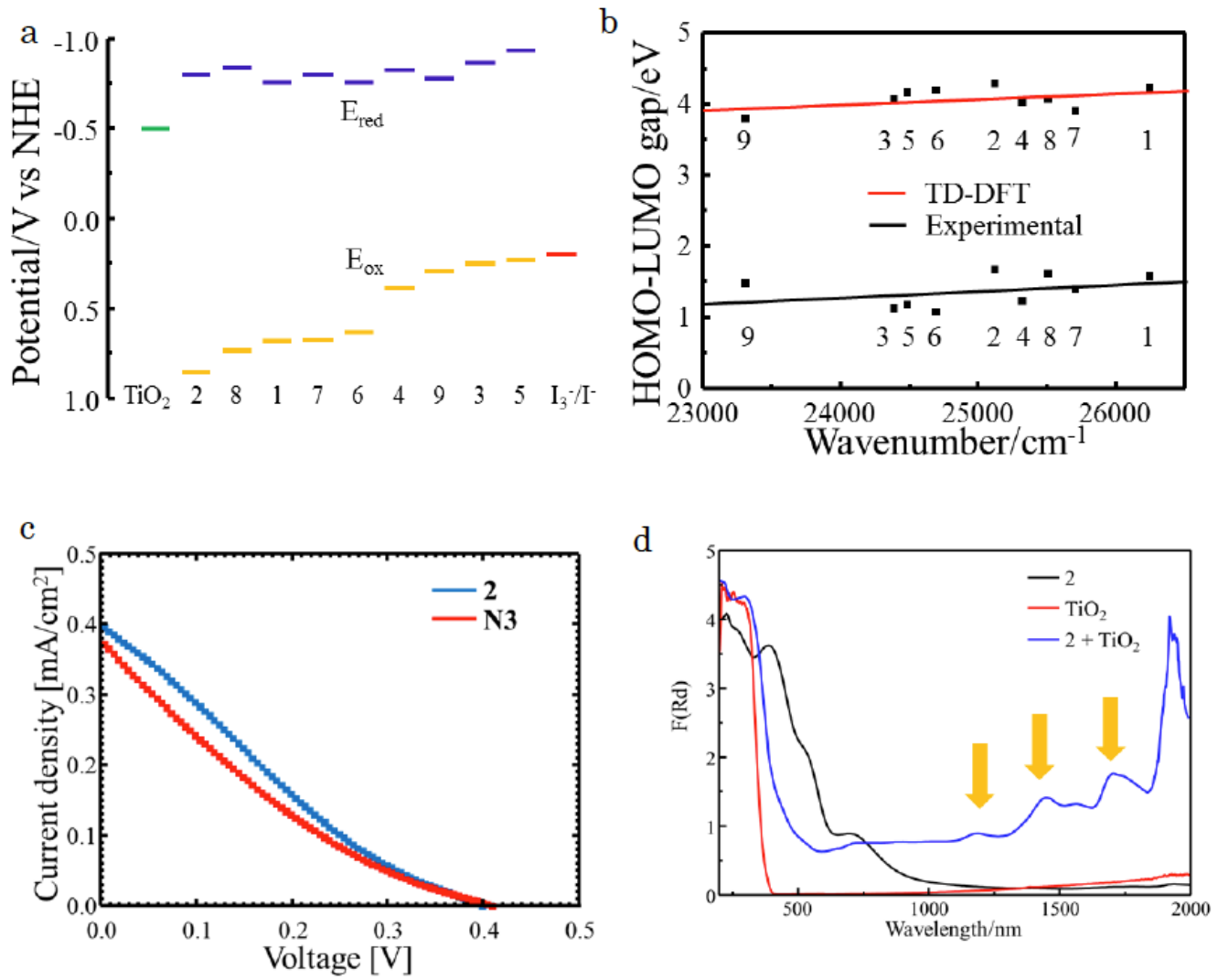

Figure 4: (a) Energy level diagrams for the prepared dyes, $\mathrm{TiO}_{2}$ and electrolyte, (b) correlation between the values for the $\pi-\pi^{*}$ band and the HOMO-LUMO gap, (c) J-V curves for DSSCs sensitized with $\mathbf{2}$ and $\mathbf{N} 3$ and (d) absorption wavelength extension because of combining 2 and $\mathrm{TiO}_{2}$

TD-DFT. In particular, the HOMO-LUMO gap increased as the wavenumber increased. In addition, the central metal did not have a noticeable effect on the differences in the values obtained for the HOMOLUMO gaps via TD-DFT calculations and experimentally. Both the calculated and measured values show a trend due to substituent effects with electron withdrawing groups causing a red-shift, which is in agreement with the results discussed above. Note that all the complexes $\mathbf{1 - 9}$ had HOMO-LUMO gaps $\leq 1.65 \mathrm{eV}$, indicating that they would be suitable as dyes with NIR absorption.

Next, devices were prepared on indium-doped tin oxide (ITO) substrates. A $\mathrm{TiO}_{2}$ paste made using polyethylene glycol (molecular weight 2000) was coated on ITO using the squeegee method. The $\mathrm{TiO}_{2}$ film on the ITO glass (active area $2.25 \mathrm{~cm}^{2}$ ) was then sintered at $723 \mathrm{~K}$ for $1 \mathrm{~h}$. The electrode was immersed immediately in a dye solution $(1 \mathrm{mmol} / \mathrm{L}, \mathrm{DMF}: \mathrm{MeOH}=$ $1: 9,24 \mathrm{~h}$ ) when the oven temperature reached $313 \mathrm{~K}$. The $\mathrm{TiO}_{2}$ electrode was then removed, flushed with acetonitrile $\left(\mathrm{CH}_{3} \mathrm{CN}\right)$ and dried under a stream of nitrogen. A solar cell was then fabricated by agglutinating carbon counter and $\mathrm{TiO}_{2}$ electrodes, followed by the injection of an electrolyte solution (0.05 $\mathrm{M} \mathrm{I}_{2}$ and $2.0 \mathrm{M} \mathrm{Lil}$ in $\mathrm{CH}_{3} \mathrm{CN}$ ), which penetrated in the $\mathrm{TiO}_{2}$ film. To investigate the performance of 1, 2, 7, 9 and N3 in DSSC, test cells were assembled as per literature procedures using an electrolyte composition typically employed for DSSCs based on N3. For the present study, the improvement of the performance of well-known types of cells was not a concern; only the performance of the complexes as dyes was investigated. Under identical conditions, the PCEs of complexes 1, 2, 7, 9 and N3 were $0.6126 \times 10^{-2} \%$, $3.3486 \times 10^{-2} \%, 0.1690 \times 10^{-2} \%, 0.7071 \times 10^{-2} \%$ and $3.0609 \times 10^{-2} \%$, respectively. The photovoltaic performance results for DSSCs based on complexes $\mathbf{1}$, 2, 7, 9 and $\mathbf{N 3}$ are listed in Table S8. The incorporation of an electron withdrawing group at position X- led to an improvement in the $J_{\text {sc }}$ value. The $J-V$ curves for the solar cells sensitised using $\mathbf{2}$ and $\mathbf{N} 3$ are shown in Figure $4 \mathrm{c}$. The change in the $\mathrm{J}_{\mathrm{sc}}$ value is prominently visible in the power conversion efficiency for 2 , in which the optimisation of the electron transfer process was achieved due the presence of both the electron withdrawing substituent and the inclusion of the carboxy group in the chiral ethylenediamine ligand. In 
particular, the LUMO for $\mathbf{2}$ was close to the conduction band of $\mathrm{TiO}_{2}$. This adsorption distance between 2 and $\mathrm{TiO}_{2}$ was optimised by the torsion angle of $\mathbf{2}$. Therefore, the contortion of the carboxy group contributed to an increase in the power conversion efficiency. The expansion of the spectral region over which light was absorbed due to the combination of 2 with $\mathrm{TiO}_{2}$ is shown in Figure $\mathbf{4 d}$. This extension of the wavelengths at which light was absorbed may explain the improved performance of $2 / \mathrm{TiO}_{2}$ compared to that of the N3 dye. The new peaks near 1200 and $1500 \mathrm{~nm}$ in the absorption spectrum of $2 / \mathrm{TiO}_{2}$ (Figure $4 \mathrm{~d}$ ) may be attributed to dipole interactions or dielectric effects. In addition, the charge transfer peak in the NIR region has been reported to be associated with an increase in interfacial stability following the adsorption of dyes on $\mathrm{TiO}_{2}$ [19]. It is therefore also thought that the charge transfer peaks in the NIR region (at approximately 1200 and $1500 \mathrm{~nm}$ ) contributed to the increased power conversion efficiency when 2 was combined with $\mathrm{TiO}_{2}$. However, the absorbed NIR light was not directly used for photoinduced electron transfer, which occurred via a complicated mechanism (coupling with electron transitions and vibrations). Further investigation is therefore required to clearly elucidate the mechanism. However, it can be concluded that such simple strategy of introducing electron withdrawing groups into wellknown salen ligands [20] bound to $\mathrm{Cu}(\mathrm{II})$ surely provides complexes with the potential for use as effective and low-cost DSSC dyes.

\section{METHODS}

\section{Preparation of 1}

To a solution of salicylaldehyde $(0.104 \mathrm{~g}, 1 \mathrm{mmol})$ dissolved in methanol $(10 \mathrm{ml})$ was added dropwise (2S,3S)-3-aminoaspartic acid ( $0.074 \mathrm{~g}, 0.5 \mathrm{mmol})$, and the resultant mixture was stirred at $313 \mathrm{~K}$ for $2 \mathrm{~h}$ to afford a yellow solution of the ligand. Copper(II) acetate monohydrate $(0.099 \mathrm{~g}, 0.5 \mathrm{mmol})$ was then added, and the solution was stirred for $2 \mathrm{~h}$. Yield $0.255 \mathrm{~g}$ (61.1\%). Anal. Calc.: C, 33.45; H, 4.34 and N, 10.64. Found: C, 33.56; H, 4.28; N, 11.58. IR ( $\left.\mathrm{KBr}, \mathrm{cm}^{-1}\right) 758(\mathrm{~m}), 1152$ (w), $1310(w), 1390(w), 1449(m), 1604(s, C=N), 1648$ (s, C=O) and 3431 (br, s). $\mathrm{T}_{\mathrm{d}}: 552.9 \mathrm{~K}$.

\section{Preparation of 2}

To a solution of 3,5-dichlorosalicylaldehyde $(0.191$ $\mathrm{g}, 1 \mathrm{mmol})$ dissolved in methanol $(10 \mathrm{ml})$ was added dropwise (2S,3S)-3-aminoaspartic acid (0.074 g, 0.5 $\mathrm{mmol}$ ), and the resultant mixture was stirred at $313 \mathrm{~K}$ for $2 \mathrm{~h}$ to afford a yellow solution of the ligand.
Copper(II) acetate monohydrate $(0.099 \mathrm{~g}, 0.5 \mathrm{mmol})$ was then added, and the solution was stirred for $2 \mathrm{~h}$. Yield $0.321 \mathrm{~g}$ (58.1\%). Anal. Calc.: C, 33.68; H, 3.26 and N, 7.55. Found: C, 33.62; H, 3.04; N, 7.78. IR $(\mathrm{KBr}$, $\left.\mathrm{cm}^{-1}\right) 598(w), 767(w), 886(w), 1153(\mathrm{~m}), 1213(w)$, $1332(\mathrm{~m}), 1391(\mathrm{~m}), 1441(\mathrm{~m}), 1520(\mathrm{~m}), 1627(\mathrm{~s}$, $\mathrm{C}=\mathrm{N}), 1651(\mathrm{~s}, \mathrm{C}=\mathrm{O}), 2908(\mathrm{~m})$ and $3433(\mathrm{br}, \mathrm{s}) . \mathrm{T}_{\mathrm{d}}$ : $531.2 \mathrm{~K}$.

\section{Preparation of 3}

To a solution of 3,5-dibromosalicylaldehyde $(0.4086$ $\mathrm{g}, 1 \mathrm{mmol})$ dissolved in methanol $(10 \mathrm{ml})$ was added dropwise (2S,3S)-3-aminoaspartic acid $(0.074 \mathrm{~g}, 0.5$ $\mathrm{mmol})$, and the resultant mixture was stirred at $313 \mathrm{~K}$ for $2 \mathrm{~h}$ to afford a yellow solution of the ligand. Copper(II) acetate monohydrate $(0.099 \mathrm{~g}, 0.5 \mathrm{mmol})$ was then added, and the solution was stirred for $2 \mathrm{~h}$. Yield $0.203 \mathrm{~g}$ (55.5\%). Anal. Calc.: C, 27.50; H, 2.31 and N, 4.58. Found: $\mathrm{C}, 27.79 ; \mathrm{H}, 2.28 ; \mathrm{N}, 4.92$. IR ( $\mathrm{KBr}$, $\left.\mathrm{cm}^{-1}\right) 592(\mathrm{w}), 720(\mathrm{w}), 754(\mathrm{w}), 883(\mathrm{w}), 1147(\mathrm{~s})$, $1216(\mathrm{~m}), 1330(\mathrm{~m}), 1415(\mathrm{~m}), 1439(\mathrm{~m}), 1502(\mathrm{~m})$, $1619(\mathrm{~s}, \mathrm{C}=\mathrm{N}), 1648(\mathrm{~s}, \mathrm{C}=\mathrm{O}), 3052(\mathrm{w}), 3332(\mathrm{w})$ and $3446(\mathrm{br}, \mathrm{s}) . \mathrm{T}_{\mathrm{d}}: 622.2 \mathrm{~K}$.

\section{Preparation of 4}

To a solution of 3,5-di-tert-butylsalicylaldehyde $(0.234 \mathrm{~g}, 1 \mathrm{mmol})$ dissolved in methanol $(10 \mathrm{ml})$ was added dropwise (2S,3S)-3-aminoaspartic acid $(0.074 \mathrm{~g}$, $0.5 \mathrm{mmol}$ ), and the resultant mixture was stirred at 313 $\mathrm{K}$ for $2 \mathrm{~h}$ to afford a yellow solution of the ligand. Copper(II) acetate monohydrate $(0.099 \mathrm{~g}, 0.5 \mathrm{mmol})$ was then added, and the solution was stirred for $2 \mathrm{~h}$. Yield $0.352 \mathrm{~g}$ (54.9\%). Anal. Calc.: C, 38.36; H, 3.08 and N, 5.84. Found: $\mathrm{C}, 38.48 ; \mathrm{H}, 2.95 ; \mathrm{N}, 5.58$. IR (KBr, $\left.\mathrm{cm}^{-1}\right) 591(w), 729(w), 1027(w), 1165(\mathrm{~m}), 1265(w)$, $1384(\mathrm{~m}), 1532(\mathrm{~m}), 1619(\mathrm{~s}, \mathrm{C}=\mathrm{N}), 1653$ (s, C=O), $2960(\mathrm{~m})$ and $3435(\mathrm{br}, \mathrm{s}) . \mathrm{T}_{\mathrm{d}}: 539.1 \mathrm{~K}$.

\section{Preparation of 5}

To a solution of $O$-vanilin $(0.129 \mathrm{~g}, 1 \mathrm{mmol})$ dissolved in methanol $(10 \mathrm{ml})$ was added dropwise (2S,3S)-3-aminoaspartic acid $(0.074 \mathrm{~g}, 0.5 \mathrm{mmol})$, and the resultant mixture was stirred at $313 \mathrm{~K}$ for $2 \mathrm{~h}$ to afford a yellow solution of the ligand. Copper(II) acetate monohydrate $(0.099 \mathrm{~g}, 0.5 \mathrm{mmol})$ was then added, and the solution was stirred for $2 \mathrm{~h}$. Yield $0.210 \mathrm{~g} \mathrm{(42.8 \% ).}$ Anal. Calc.: C, 42.34; H, 3.74 and N, 5.20. Found: C, 42.38; H, 3.63; N, 5.11. IR ( $\left.\mathrm{KBr}, \mathrm{cm}^{-1}\right) 617(\mathrm{w}), 667(\mathrm{w})$, $746(\mathrm{w}), 855(\mathrm{w}), 1147(\mathrm{~s}), 1216(\mathrm{~m}), 1330(\mathrm{~m}), 1415$ $(\mathrm{m}), 1439(\mathrm{~m}), 1502(\mathrm{~m}), 1604(\mathrm{~m}), 1623(\mathrm{~s}, \mathrm{C}=\mathrm{N})$, 1707 (s, C=O), $3052(\mathrm{w}), 3332(\mathrm{w})$ and $3446(\mathrm{br}, \mathrm{s}) . \mathrm{T}_{\mathrm{d}}$ : $530.5 \mathrm{~K}$. 


\section{Preparation of 6}

To a solution of 2,3-dihydroxybenzaldehyde $(0.138$ $\mathrm{g}, 1 \mathrm{mmol})$ dissolved in methanol $(10 \mathrm{ml}),(2 S, 3 S)-3-$ Aminoaspartic acid $(0.074 \mathrm{~g}, 0.5 \mathrm{mmol})$ was added dropwise and stirred at $313 \mathrm{~K}$ for $2 \mathrm{~h}$ to give a yellow solution of the ligand. Copper(II) acetate monohydrate $(0.099 \mathrm{~g}, 0.5 \mathrm{mmol})$ were added and stirred for $2 \mathrm{~h}$.

Yield $0.251 \mathrm{~g}$ (55.7 \%). Anal. Calc.: C, 42.34; H, 3.74; N, 5.20. Found: C, 42.38; H, 3.63; N, 5.11. IR $\left(\mathrm{KBr}, \mathrm{cm}^{-1}\right) 642(\mathrm{w}), 860(\mathrm{w}), 1128(\mathrm{~m}), 1197(\mathrm{w}), 1237$ (s), $1386(\mathrm{~m}), 1435(\mathrm{~m}), 1564(\mathrm{~m}), 1623(\mathrm{~s}, \mathrm{C}=\mathrm{N}), 1707$ (s, C=O), $2856(\mathrm{w}), 2925(\mathrm{~m}), 3431$ (br, s). $\mathrm{T}_{\mathrm{d}}: 544.9 \mathrm{~K}$.

\section{Preparation of 7}

To a solution of 5-chlorosalicylaldehyde $(0.156 \mathrm{~g}, 1$ mmol) dissolved in methanol $(10 \mathrm{ml}),(2 S, 3 S)-3-$ Aminoaspartic acid $(0.074 \mathrm{~g}, 0.5 \mathrm{mmol})$ was added dropwise and stirred at $313 \mathrm{~K}$ for $2 \mathrm{~h}$ to give a yellow solution of the ligand. Copper(II) acetate monohydrate $(0.099 \mathrm{~g}, 0.5 \mathrm{mmol})$ were added and stirred for $2 \mathrm{~h}$.

Yield $0.343 \mathrm{~g}$ (70.6 \%). Anal. Calc.: C, 38.36; H, 3.08; N, 5.84. Found: C, 38.48; $\mathrm{H}, 2.95 ; \mathrm{N}, 5.58$. IR $\left(\mathrm{KBr}, \mathrm{cm}^{-1}\right) 661$ (w), $829(\mathrm{w}), 1156(\mathrm{w}), 1493(\mathrm{~m}), 1623$ $(\mathrm{s}, \mathrm{C}=\mathrm{N}), 1683(\mathrm{~s}, \mathrm{C}=\mathrm{O}), 2237(\mathrm{w}), 2921(\mathrm{w}), 2921(\mathrm{w})$, $3456(\mathrm{br}, \mathrm{s}) . \mathrm{T}_{\mathrm{d}}: 549.7 \mathrm{~K}$.

\section{Preparation of 8}

To a solution of 5 -bromosalicylaldehyde $(0.2934 \mathrm{~g}$, $1 \mathrm{mmol})$ dissolved in methanol $(10 \mathrm{ml}),(2 S, 3 S)-3$ Aminoaspartic acid $(0.074 \mathrm{~g}, 0.5 \mathrm{mmol})$ was added dropwise and stirred at $313 \mathrm{~K}$ for $2 \mathrm{~h}$ to give a yellow solution of the ligand. Copper(II) acetate monohydrate $(0.099 \mathrm{~g}, 0.5 \mathrm{mmol})$ were added and stirred for $2 \mathrm{~h}$.

Yield $0.134 \mathrm{~g}$ (46.5 \%). Anal. Calc.: C, 32.27; H, $1.81 ; \mathrm{N}, 4.18$. Found: $\mathrm{C}, 32.65 ; \mathrm{H}, 1.91 ; \mathrm{N}, 4.18$. IR $\left(\mathrm{KBr}, \mathrm{cm}^{-1}\right) 542(\mathrm{w}), 611(\mathrm{w}), 649(\mathrm{w}), 706(\mathrm{w}), 800(\mathrm{w})$, $834(\mathrm{~m}), 894(\mathrm{w}), 944(\mathrm{w}), 944(\mathrm{w}), 1073(\mathrm{w}), 1186(\mathrm{~m})$, 1273 (s), 1368 (s), $1468(\mathrm{~m}), 1536(\mathrm{~m}), 1606(\mathrm{~s}, \mathrm{C}=\mathrm{N})$, 1652 (s, C=O), 2943 (w), 3092 (w), 3429 (br, s). Td: $568.4 \mathrm{~K}$

\section{Preparation of 9}

To a solution of 2-hydroxy-5-methoxybenzaldehyde $(0.124 \mathrm{~g}, 1 \mathrm{mmol})$ dissolved in methanol $(10 \mathrm{ml})$, $(2 S, 3 S)$-3-Aminoaspartic acid $(0.074 \mathrm{~g}, 0.5 \mathrm{mmol})$ was added dropwise and stirred at $313 \mathrm{~K}$ for $2 \mathrm{~h}$ to give a yellow solution of the ligand. Copper(II) acetate monohydrate $(0.099 \mathrm{~g}, 0.5 \mathrm{mmol})$ were added and stirred for $2 \mathrm{~h}$.
Yield $0.307 \mathrm{~g}$ (64.3 \%). Anal. Calc.: C, 37.91; H, 3.89; N, 8.19. Found: C, 37.69; H, 3.77; N, 8.48. IR $\left(\mathrm{KBr}, \mathrm{cm}^{-1}\right) 591(\mathrm{w}), 809(\mathrm{w}), 1027(\mathrm{w}), 1116(\mathrm{w}), 1165$ $(\mathrm{w}), 1294(\mathrm{~m}), 1384(\mathrm{~m}), 1384(\mathrm{~m}), 1473(\mathrm{w}), 1611$ $(\mathrm{C}=\mathrm{N}), 1647(\mathrm{C}=\mathrm{O}), 2920(\mathrm{w}), 3435(\mathrm{br}, \mathrm{s}) . \mathrm{T}_{\mathrm{d}}: 543.0 \mathrm{~K}$.

\section{X-Ray Crystallography}

The powder X-ray diffraction patterns of complexes 1, 2, 4 and 6 were obtained at $298 \mathrm{~K}$ on a Rigaku Smart Lab system at the University of Tokyo. Structural analyses were performed using the Rietveld method [S3] and PDXL2 ver.2.2.1.0 (Rigaku Corporation). Although 1, 2, 4 and 6 are chiral molecules, they are solved as space group $P 2_{1} / \mathrm{n}$ to indicate reasonable density because of uncertain systematic absence of powder diffraction.

\section{Computation}

All calculations were performed using the Gaussian 09W software Revision A.02 (Gaussian, Inc.). The gasphase geometry optimisations were performed using TD-DFT with the B3LYP functional. The vertical excitation energies were calculated using the LanL2DZ method for $\mathrm{Cu}$ with the $6-31+\mathrm{G}(\mathrm{d})$ basis set for $\mathrm{H}, \mathrm{C}, \mathrm{N}$, $\mathrm{O}, \mathrm{Cl}$ and $\mathrm{Br}$ and based on the singlet ground-state geometry.

\section{Measurements}

Elemental analyses $(\mathrm{C}, \mathrm{H}$ and $\mathrm{N})$ were performed using a Perkin-Elmer 2400 II CHNS/O analyser at the Tokyo University of Science. IR spectra were recorded as $\mathrm{KBr}$ pellets on a JASCO FT-IR 4200 plus spectrophotometer in the range $4000-400 \mathrm{~cm}^{-1}$ at 298 $\mathrm{K}$. Absorption spectra were obtained on a JASCO V570 UV-vis-NIR spectrophotometer in the range 2000-200 nm at $298 \mathrm{~K}$. CD spectra were obtained on a JASCO J-820 spectropolarimeter in the range 900-250 $\mathrm{nm}$ at $298 \mathrm{~K}$. TG-DTA profiles were obtained in air at a heating rate of $10 \mathrm{Kmin}^{-1}$ using a Rigaku TG8120. CV curves were obtained via BAS AIS/DY2323 using a traditional three-electrode system. The working, reference and auxiliary electrodes were a Pt disk, $\mathrm{Ag} / \mathrm{AgCl}$ and $\mathrm{Pt}$ wire, respectively. The performance of DSSCs was determined from $J-V$ curves obtained under air mass 1.5 conditions at an illumination of 100 $\mathrm{mW} / \mathrm{cm}^{2}$ using an ADCMT 6241A DC voltage/current source/monitor. All measurements were performed at room temperature. 


\section{ACKNOWLEDGEMENTS}

The computations were performed at the Research Center for Computational Science, Okazaki, Japan. This study was partly supported by 'Nanotechnology Platform' (project No. A-14-UT-0277) from the Ministry of Education, Culture, Sports, Science and Technology (MEXT), Japan.

\section{SUPPLEMENTARY INFORMATION}

The supplementary information can be downloaded from the journal website along with the article.

\section{REFERENCES}

[1] Nazeeruddin MK, Kay A, Rodicio I, et al. Conversion of light to electricity by cis-X2bis(2,2'-bipyridyl-4,4'-dicarboxylate) ruthenium(II) charge-transfer sensitizers $(\mathrm{X}=\mathrm{Cl}-, \mathrm{Br}-, \mathrm{I}-, \mathrm{CN}-$, and $\mathrm{SCN}-$ ) on nanocrystalline titanium dioxide electrodes. $\mathrm{J}$ Am Chem Soc 1993; 115: 6382-90. http://dx.doi.org/10.1021/ja00067a063

[2] Hagfeldt A, Boschloo G, Sun L, Kloo L, Pettersson H. DyeSensitized Solar Cells. Chem Rev 2010; 110: 6595-663. http://dx.doi.org/10.1021/cr900356p

[3] Brewster TP, Konezny SJ, Sheehan SW, et al. Hydroxamate anchors for improved photoconversion in dye-sensitized solar cells. Inorg Chem 2013; 52: 6752-64. http://dx.doi.org/10.1021/ic4010856

[4] Komatsu M, Nakazaki J, Uchida S, Kudo T, Segawa H. A donor-acceptor type organic dye connected with a quinoidal thiophene for dye-sensitized solar cells. Phys Chem Chem Phys 2013; 15: 3227-32. http://dx.doi.org/10.1039/c2cp43598e

[5] Brown DG, Schauer PA, Borau-Garcia J, Fancy BR, Berlinguette $\mathrm{CP}$. Stabilization of ruthenium sensitizers to TiO2 surfaces through cooperative anchoring groups. J Am Chem Soc 2013; 135: 1692-5. http://dx.doi.org/10.1021/ja310965h

[6] Wang $\mathrm{D}, \mathrm{Wu} \mathrm{Y}$, Dong $\mathrm{H}$, et al. Iridium (III) complexes with 5,5-dimethyl-3-(pyridin-2-yl)cyclohex-2-enone ligands as sensitizer for dye-sensitized solar cells. Organic Electronics 2013; 14: 3297-305 http://dx.doi.org/10.1016/j.orgel.2013.09.040

[7] Sinn S, Schulze B, Friebe C, et al. A heteroleptic bis(tridentate) Ruthenium(II) platform featuring an anionic 1,2,3-triazolate-based ligand for application in the dyesensitized solar cell. Inorg Chem 2014; 53: 1637-45. http://dx.doi.org/10.1021/ic402701v

[8] Nazeeruddin MK, Pechy P, Renouard T, et al. Engineering of efficient panchromatic sensitizers for nanocrystalline TiO2based solar cells. J Am Chem Soc 2001; 123: 1613-24. http://dx.doi.org/10.1021/ja003299u
Pogozhev DV, Bezdek MJ, Schauer PA, Berlinguette CP. Ruthenium(II) complexes bearing a naphthalimide fragment: a modular dye platform for the dye-sensitized solar cell. Inorg Chem 2013; 52: 3001-3006.

http://dx.doi.org/10.1021/ic3024524

[10] Mathew S, Yella A, Gao P, et al. Dye-sensitized solar cells with $13 \%$ efficiency achieved through the molecular engineering of porphyrin sensitizers. Nature Chem 2014; 6 : 242-7.

http://dx.doi.org/10.1038/nchem.1861

[11] Lee KE, Gomez MA, Regier T, Hu Y, Demopoulos GP. Further understanding of the electronic interactions between N719 sensitizer and anatase TiO2 films: a combined X-ray absorption and X-ray photoelectron spectroscopic study. J Phys Chem C 2011; 115: 5692-707. http://dx.doi.org/10.1021/jp109869z

[12] Honda M, Yanagida M, Han L, Miyano K. X-ray characterization of dye adsorption in coadsorbed dyesensitized solar cells. J Phys Chem C 2013; 115: 17033-8. http://dx.doi.org/10.1021/jp404572y

[13] Tanaka $H$, Nishikawa $H$, Uchida $T$, Katsuki $T$. Photopromoted Ru-catalyzed asymmetric aerobic sulfide oxidation and epoxidation using water as a proton transfer mediator. J Am Chem Soc 2010; 132: 12034-41. http://dx.doi.org/10.1021/ja104184r

[14] Nakamura Y, Egami H, Matsumoto K, Uchida T, Katsuki T. Aerobic oxidative kinetic resolution of racemic alcohols with bidentate ligand-binding $\mathrm{Ru}($ salen) complex as catalyst. Tetrahedron 2007; 63: 6383-7. http://dx.doi.org/10.1016/j.tet.2007.03.105

[15] Jia Y, Gou F, Fang R, Jing H, Zhu Z. SalenZn-bridged D-т-A dyes for dye-sensitized solar cells. Chin J Chem 2014; 32 513-20. http://dx.doi.org/10.1002/cjoc.201300924

[16] Hwang KY, Kim H, Lee YS, Lee MH, Do Y. Synthesis and properties of salen-aluminum complexes as a novel class of color-tunable luminophores. Chem Eur J 2009; 15: 6478-87. http://dx.doi.org/10.1002/chem.200900137

[17] Govorov AO, Fan Z, Hernandez P, Slocik JM, Naik RR Theory of circular dichroism of nanomaterials comprising chiral molecules and nanocrystals: plasmon enhancement, dipole interactions, and dielectric effects. Nano Lett 2010; 10 1374-82.

http://dx.doi.org/10.1021/nl100010v

[18] Aritake $Y$, Nakayama T, Nishizuru H, Akitsu T. Observation of induced $C D$ on CdSe nanoparticles from chiral Schiff base $\mathrm{Ni}(\mathrm{II}), \mathrm{Cu}(\mathrm{II}), \mathrm{Zn}$ (II) complexes. Inorg Chem Commun 2011; 14: 423-5.

http://dx.doi.org/10.1016/j.inoche.2010.12.017

[19] Liu Y, Lin H, Li J, et al. Ethynyl-linked push-pull porphyrin hetero-dimers for near-IR dye-sensitized solar cells: photovoltaic performances versus excited-state dynamics. Phys Chem Chem Phys 2012; 14: 16703-12.

\section{http://dx.doi.org/10.1039/c2cp43165c}

[20] Orita S, Akitsu T. Variety of crystal structures of chiral schiff base $\mathrm{Lu}(\mathrm{III})-\mathrm{Ni}(\mathrm{II}) / \mathrm{Cu}(\mathrm{II}) / \mathrm{Zn}$ (II) and the related complexes. Open Chem J 2014; 1: 1-14. http://dx.doi.org/10.2174/1874842201401010001

(c) 2016 Shoji et al.; Licensee Lifescience Global.

This is an open access article licensed under the terms of the Creative Commons Attribution Non-Commercial License (http://creativecommons.org/licenses/by-nc/3.0/) which permits unrestricted, non-commercial use, distribution and reproduction in any medium, provided the work is properly cited. 